\title{
Symposium Summary: The State of Canada's Constitutional Democracy
}

\section{Cheryl Milne, John Greiss, and Deborah Boswell ${ }^{1}$}

\section{Introduction}

Dramatic changes have taken place in recent years at the national level with respect to the day to day functioning of our constitutional democracy. These changes impinge on the separation of powers, the rule of law and the supremacy of the constitution. The David Asper Centre for Constitutional Rights at the University of Toronto ${ }^{2}$ partnered with the Centre for Constitutional Studies at the University of Alberta ${ }^{3}$ to organize a two day symposium in February 2016, at the Faculty of Law, University of Toronto, designed to bring together a diverse group of academic experts and individuals with experience in public service at high levels, as well as academics with personal experience in governance, to discuss these changes.

Our deliberations focused upon the extent to which modern constitutional principles and Canadian governance practices have converged and diverged in the recent past. We also deliberated upon the distinctive roles that public institutions make, individually and in collaboration, in supporting and developing fidelity to constitutional principles. These principles include the rule of law (including constitutional law); the separation of powers as between the executive, the legislature and the judiciary; democracy as it relates to the conduct of elections, vibrant debate in the legislative and public fora based on a full factual foundation, rational deliberation, transparency and accountability; deliberative and co-operative federalism; the independence of the judiciary; and the duty to respect and protect the fundamental rights and freedoms of all residents and citizens of Canada.

To enlarge our perspectives, a leading academic $^{4}$ from the United Kingdom was invited to participate in the full symposium, chosen on the basis of his participation in the recent extensive reconfiguration of the most important institutions of governance to instantiate these modern constitutional principles. This transformation of the Westminster model of governance - its process, substantive commitments and implementation - provided a much needed model for Canada. It demonstrated the importance, urgent need for, and feasibility of extensive constitutional modernization. His remarks are summarized in the conclusion.

Key academics and policy experts were invited to give brief presentations on the various topics summarized below. They were invited to pose questions to the other symposium participants to foster discussion on what were the key issues and how Canada can best move forward. Those questions are listed in Appendix C. The discussion was at times wide-ranging but always focused on the key principles and issues facing Canada's constitutional democracy. The following attempts to capture some of the discussion by focussing on the major themes of each session. ${ }^{5}$ More detailed treatment of specific subject areas can be found in the symposium papers published 
in this issue of the Constitutional Forum and noted in each section below.

On February 26, 2016, the panel members and a number of invited experts discussed additional issues over dinner. The questions that were asked at each table sparked a facilitated and loosely recorded discussion about what are the most urgent issues that need to be addressed in Canada. The two key questions were:

1. We are now getting used to the dramatic changes precipitated by the recent election and moving toward the 150th anniversary of the birth of the Canadian state. Looking back and looking forward, can we work out a template of the most urgent topics and themes for constitutional development and renovation?

2. Given our history of formal and informal constitutional change, and the example that recent constitutional development in the United Kingdom provides, what should we include in an agenda for short and long terms projects to update and fill gaps in the structure and operation of Canada's constitutional democracy?

A list of the ideas this discussion elicited can be found at Appendix B.

\section{A. Democratic process: elections, funding duration, franchise, omni- bus bills, retroactive legislation, government formation}

The symposium began with a discussion about some of the nuts and bolts of how democracy functions in Canada. The panelists focused specifically on the proper use of omnibus bills, the process by which government is formed and dissolved, and electoral reform. Regarding omnibus bills, the panelists and discussants acknowledged their increasing use as a political tool to push through unpopular provisions and curtail the ability of the opposition to scrutinize disparate laws and hold government accountable. It was noted that omnibus bills had come to represent $30-40 \%$ of all legislative output in the last few years. The essential defence of omnibus legislation, though it may seem to create or amend disparate statutes, is a single purpose which brings together all enactments making it intelligible for parliamentary purposes. One example of their use was Quebec's section 33 override of Charter rights. While the Supreme Court of Canada ultimately accepted that it could be implemented through an omnibus bill, it was seen as a heavyhanded approach to overriding fundamental Charter rights with insufficient opportunity for discussion and debate.

Discussion turned to the UK experience for suggestions on how to tackle the difficulties with omnibus bills to make them workable. First, a Committee on Delegated Powers in the House of Lords scrutinizes every bill for powers conferred on Ministers and waves a red flag where it feels the order-making power is too great. Second, a Secondary Legislation Scrutiny Committee functions to examine secondary legislation in omnibus bills to assess its merits and draw attention to concerning provisions. Each of these committees serves to keep omnibus bills in check, given that they are very influential and met with fierce opposition. However, some participants questioned whether the Supreme Court of Canada would be institutionally willing to take a more active role in the political process in this way.

One panel member focused on government formation and the general lack of knowledge by the public about Canada's constitutional conventions in this regard. A background paper posited the view that, "Popular misunderstandings of the rules and principles leading to the formation of government may lead to a crisis of confidence in our democratic institutions."' This raised the issues of prorogation along with the role of the Governor General and the rules governing when the Prime Minister has the confidence of the House. Another panel member suggested ways in which some of these rules could be modified without the need for full constitutional amendments. ${ }^{7}$ It was suggested that it would be a perverse consequence of the patriation of our constitution to be tied to rigid rules of the Westminster model, while the United Kingdom, upon which it is based, is able to modernize more easily. 
The second half of the discussion focused on electoral reform, and many wondered whether the Reference re Supreme Court Act ${ }^{8}$ and the Senate reference ${ }^{9}$ served as harbingers for finding the current electoral process to be constitutionally entrenched. On the other hand, two panelists argued that such changes could be made unilaterally by Parliament. ${ }^{10}$ This comes from a plain reading of the constitutional texts whereby anything that is not explicitly set out might be inferred to be within Parliament's authority to change. This was also favoured from the point of view of expediency, to allow elected officials to bring forward their best proposal and debate openly, rather than simply trying to accommodate the vested interests that arise from constitutional amendments. That is, for omnibus bills, electoral reform, or any other change to the democratic process, the conference participants agreed that the constitutional texts and conventions ought to be viewed as a way to protect democracy and, when functioning properly, should not be an impediment to democratic reforms.

\section{B. Constitutionalism, adminis- tration of justice and rule of law}

Simply recognizing constitutional conventions can be difficult. The panelists in this session discussed the legislative process, including review for constitutional impact, and access to government information, highlighting a selection of government activities that are not clearly recognized as part of a constitutional convention or activities that ought to be scrutinized for constitutionality. For example, ministerial advice to the Crown is typically treated as a command rather than advice. The discussion suggested that it may be helpful to subject that advice to a legal duty and so require the Ministers to provide public rationale and justification for their decisions. This may have been useful, for example, when the previous Prime Minister advised the Governor General to prorogue government, at which time the rationale for the decision was hidden from the public's knowledge. Two papers delved into the advice aspect of the legislative process in more depth. ${ }^{11}$ One point noted in the discussion was that the notion that oversight of this aspect of the process impedes governance is often overplayed. If we have a parliamentary committee that looks at the constitutionality of legislation, there should be no reason why there should not also be a publicly available discussion paper that parliamentarians may consider in terms of an enactment's constitutional vulnerabilities. The UK has created specialist committees that scrutinize every bill for constitutional issues and issue reports that are highly influential, such that the government has been regularly defeated in the House of Lords on legal and constitutional grounds.

The committee stage of the legislative process serves as another example for recognizing constitutional conventions and increasing transparency. ${ }^{12}$ This includes the reasons for selecting the witnesses to the committee, the notice with which members are given to participate in the committee to allow for adequate preparation, and the ability to access briefs or follow the evolution of proposed amendments emerging from the committee. One panel member noted the extreme partisan and negative tone that committees had adopted in the most recent past. Establishing constitutional conventions in this area is necessary to ensure the process is fair, transparent, and upholds the requirements of the rule of law.

While each of these areas was recognized as an important topic for consideration, much of the discussion focused on access to information. ${ }^{13}$ The Supreme Court ruling that the PMO and Ministers' offices were not institutions of government and so not subject to access to information requests was regarded as a setback to increased transparency and accountability. One panelist noted that this is but one example of a long history of eroding public access to information, especially in a political climate that emphasizes the anti-terrorism rhetoric. A participant noted that the freedom of the media, an explicitly protected Charter right, is seriously affected by a government that refuses to speak to the media. The concern about not being able to access information through access requests becomes secondary to this communication dysfunction. It was 
also noted that any reform to access to information must propose a workable system for government response to enable the curtailment of some vexatious individuals who do not use the system responsibly. Finally, changes to government sponsored information producing agencies, such as the limits placed on Statistics Canada and the defunding of the National Council of Welfare, represented a symbolic and ideological narrowing of who counts in our democracy. ${ }^{14}$

\section{Democratic function: roles of the house of commons, senate, cabinet, $\mathrm{PMO}$, and individual ministers}

In November 2008, then minority leader and Prime Minister Stephen Harper avoided a nonconfidence vote that would have seen the prime ministerial office shift to one of the minority leaders in the house. He did so by proroguing Parliament, the first Prime Minister to do so in this manner in Canadian history. He would use this power again in 2010, and this time many suspected it was an attempt to muzzle parliamentarians amid controversy over the Afghan detainees affair. The ability for a minority government to avoid political failures by what was seen as a manipulation of government procedures provided the backdrop for a panel on the importance of increasing transparency and codifying some constitutional conventions.

To that end, the panelists and participants discussed the merits of a cabinet manual and a catalogue of prerogative powers for the executive. A cabinet manual would include principles, practices, and rules of parliamentary and cabinet government. While non-binding, the panelists discussed how the increased transparency and codification of constitutional norms would assist holding the executive accountable and would highlight the politicizing of certain democratic functions. Others discussed a more formal codification process for some prerogative powers, especially the war-making, treaty-making, and prorogation powers. One panel member noted that in the case of Roncarelli $v$ Duplessis,${ }^{15}$ Justice Rand held that the rule of law is a fundamental postulate of the Canadian constitutional order not to be superseded by arbitrary actions of public officers and to hold otherwise would be the beginning of the disintegration of this fundamental principle. ${ }^{16}$ The panel member noted the obvious tension between this principle and the persistence of prerogative powers which are by definition arbitrary. A number of parliamentary democracies have recognized this problem, created a catalogue of prerogative powers and examined whether they should be removed. Canada has not even thought through what should be included in such a catalogue.

A cabinet manual was also discussed as having a more pragmatic purpose rather than as an instrument for reform. Part of the discussion lamented the lack of training for new parliamentarians and the steep learning curve that came for a newly-elected representative. A comparison was made to the US experience, where the Congressional Research Services conducts seminars for all new members of Congress and provides more advanced classes for people who want more information on procedure. In this sense, a cabinet manual would be seen as an essential part of ensuring a more efficient and productive government, rather than simply as a tool for increasing accountability, and would help avoid the surprise and confusion that appeared to accompany the first attempt to prorogue government in 2008. In a similar fashion, a cabinet manual would help to increase the constitutional literacy of the public, thereby allowing for another level of accountability and civic engagement. ${ }^{17}$

There was discussion, however, on the drawbacks of a cabinet manual or the codification of certain prerogative powers. One concern was that writing down constitutional conventions will inevitably lead to their being litigated, and some participants were concerned about giving the courts an influence on certain outcomes, such as the declaration of war. Others questioned whether a codification was meaningful given the intrinsic discretionary nature of the prerogative power as an arbitrary executive power. Others still suggested that no government would be willing to give up the discretionary nature of certain prerogative powers by having them formally codified. Nevertheless, many agreed that 
if the cabinet manual set up a framework for governance a priori, it would serve as a basis for discussion when the executive was suspected for using certain constitutional conventions for political purposes.

Another panelist cited concern about a government's ability to limit the circle of inclusion in important decision-making, such as limiting the access of the Clerk of the Privy Council's Office to the Prime Minister's Office. Given that the role of the PCO is centralization, responsibility for the continuity of governance, and coordination, there was a concern that marginalizing the Clerk reduced its influence. An example of this was the incident of a staffer providing the Prime Minister with legal advice surrounding the Duffy trial, whereas this type of legal advice was thought to be exclusively the role of the Attorney General. All in all, the overarching concern was that the PCO is becoming increasingly politicized, and this may eventually lead to a less functional, and perhaps even dysfunctional, executive.

\section{Constitutional governance and litigation}

The discussion on constitutional governance and litigation focused on the government's role and expectations in responding to constitutional challenges and findings of invalidity. The overarching focus of the presenters and participants was the concern over the lack of avenues by which to hold the government accountable to governance norms and the response to constitutional challenges that may not align with the political party in control of the executive. One presenter discussed how the government could express defiance or test the limits of their constitutional powers and the separation of powers. ${ }^{18}$ The previous government's moratorium on appointing senators was cited as an example of the type of obstructionist behaviour that could be appropriately characterized as unconstitutional under the Constitution Act, 1867.

The panel and other participants cited other examples of inaction that could likewise be viewed as politically motivated, even without pointing to an explicit constitutional text. For example, the Criminal Code continues to contain a number of provisions which have been struck down by the courts, and the Canada Elections Act continues to read that prisoners do not have the right to vote, despite court rulings to the contrary. Similarly, the Khadr ${ }^{19}$ decision was not acted upon promptly. Some regarded this as a degree of passive aggressiveness that can be interpreted as a disregard for the judicial branch.

However, there were also more principled concerns regarding the limit of the court's remedial discretion in constitutional litigation and its implications for the rule of law. It was acknowledged, for example, that the practical reality of failing to rectify statutes was that the public can no longer simply read the legislation and know their rights without the aid of a lawyer. One commenter likewise suggested that legislative titles themselves can be used to express certain ideological and political views, rather than providing clarity as to the law's purpose and providing notice to the public. Suggestions to prevent these types of problems included raising the possibility of codifying or otherwise developing constitutional norms that might require the government to take positive steps to remedy these defects. Indeed, some of the discussion focused on the UK experience where there does appear to be a clear convention that when the court issues a finding of validity, parliament will respond with compliant legislation and not simply acquiesce. The UK now has a requirement that all bills must be accompanied by a certificate where the sponsoring minister attests the bill is compatible with European Convention on Human Rights. A joint committee can then scrutinize the bill and interrogate a Minister as to the reasoning for compatibility. This would help curb the temptation to introduce legislation that might have been introduced in bad faith knowing that it might take 10 years to be finally declared invalid at the Supreme Court level.

Inaction was seen as but one way that the government in power might be defiant to its constitutional obligations. There were other nonlegal efforts cited by the attendants as to how the executive branch might try to exert influence and perhaps even intimidate other branches of gov- 
ernment. Recent examples included comments made by the Minister of Health and Minister of Justice that certain Supreme Court decisions were a product of court members' political bias. A more egregious example was the government's direct accusation that the Chief Justice actively campaigned against the appointment of Justice Nadon. However, there was also a growing concern that this type of influence might even be exercised between the PMO and other areas of the executive branch itself. The Department of Justice, as an example, was not consulted in the final two judicial appointments by the Harper government. The panelists expressed deep concern that such actions failed to recognize the Prime Minister's office as a constitutional actor, not simply a political actor. To that end, it was suggested that it may be time to expand the constitutional norm as to who is properly considered a constitutional actor, beyond simply the Governor General and Prime Minister, to include all Ministers.

This usurping of the government offices for political gains concerned many of the participants. That is, not only might the government ignore or only minimally abide by a court's orders to meet certain constitutional obligations, but there was a concern that the tone and culture set by the PMO might even mobilize certain government actions for political ends. One participant provided his firsthand experience in dealing with certain parliamentary matters, and stressed the importance that reverence and respect for the office influences the actions of those who hold them, and serve to instil a fidelity to constitutional norms even if those actions are not specific exercises of power or legislative acts. Therefore, while government lawyers may view their client as the government, there ought to continue to be a concern for protecting the public interest and acknowledging a higher duty, rather than simply maximizing the position of the government. It was noted that some criticism of government lawyers failed to take into account the role that courts have given them in terms of their ethical duties and that courts have rejected the approach that requires a higher ethical or public interest duty on them. One participant talked about a culture of intimidation and the ignoring of legal advice from government lawyers that was pervasive over the last 10 years. Ultimately, it was agreed that it is the culture inculcated by the government of the day that likely influences the approach that government lawyers take to litigation.

Others suggested splitting the role of the Attorney General and Minister of Justice. AGs should be accountable for administering the law in a way that constructs social solidarity, diminishes social damage, pays attention to the social realities, and is accountable to the Cabinet - to be less criminogenic, more constructive members of the legal community. On the other hand, some felt that this would not necessarily solve the conflict of interest problem that the joint position currently faces, namely advancing the political agenda versus defending rights and upholding the constitution and rule of law. On the whole, what was clear was the need to more clearly articulate the constitutional norms about the conduct of government in order to ensure that fundamental values and expectations were being met, even in the absence of a formal constitutional amendment.

The Charter was a pivotal moment in holding Parliament accountable, and the move from a parliamentary democracy to a constitutional democracy, where individuals were no longer passive participants in constitutional governance but active rights claimants with standing, shifted the power dynamics in ways that subsequent governments have not always readily acknowledged. However, the reliance on courts has its limits. It was noted in the discussion that the courts have often afforded significant deference to government, at times considered excessive, in the face of questionable legislation. The shift of the use of the suspended declaration of invalidity from an exception to the norm was cited as a worrisome practice. The remedy can create an incentive for Parliament to not take its job seriously and to fail to move quickly to remedy a problem. Concern was expressed about the use of this remedy in a case where the legislation was held to be putting people's lives as risk. This caution about the reliance on courts was expressed also by the clear consensus that it is not just the 
courts that are responsible for upholding Charter rights and values, but that it should engage all three branches of government.

\section{E. Public appointments: procedure, independence, merit, transparency}

The final panel explored options for increasing transparency and accountability for the executive's powers for judicial and senate appointments. With respect to judicial appointments, there appeared to be a consensus that in recent years, the appointment process in Canada has become less substantive, less transparent and more partisan in nature..$^{20}$ The discussion focused on the previous government's retreat from a more transparent, albeit imperfect, process and the Supreme Court's decision rejecting the appointment of Justice Nadon. Part of the desire for increased transparency and a more formalized appointment process would be not only to serve as a check on the Prime Minister's power, but to also establish norms that could rise to the level of creating greater constitutional muscle.

Justice Brown's appointment to the Supreme Court only two days before a national election was criticized as unseemly. Many expressed their concern that the Prime Minister ought not to be able make major decisions that would affect the lives of Canadians so far into the future just days before his possible ouster. There was discussion as to whether the Prime Minister's powers of appointment ought to be truncated leading up to the election, and whether a new constitutional norm to that effect might be recognized. The general feeling was that these actions were the harbingers of a more partisan mindset in the appointment process than ever before in Canadian history.

Suggestions to ameliorate the process included a greater need for record-keeping which would allow the review of documents related to the parliamentary committee's appointment process - this would create a more resilient process. The panelists stressed that whatever the accountability process that was adopted, it ought to emphasize the appointee's merits and, for judges, their constitutional decision-making. Others explored the possibility of giving Parliament a greater role in the appointment process, such as in the confirmation of the Chief Justice. This would make the executive accountable to Parliament, improve transparency, and serve as an introduction of the appointee to the Canadian public. The US Senate confirmation hearings appear to have negatively affected such a move in the UK, where the appointment process was recently reformed. The trepidation may now be heightened given the current struggles of appointing a new justice to the US Supreme Court.

There were concerns expressed about overprotecting against partisanship at the expense of other goals. Many agreed that partisanship on the Supreme Court is typically less of a concern in Canada than in the US. Furthermore, there may be ways to reduce the effects of partisanship external to the appointment process. Experience from the UK has shown that an increase in the opportunities for face-to-face dialogue between legislators and the judiciary have been well accepted as they allow for better understanding of the reasons behind enacting or interpreting legislation in more contentious areas. This may include regular meetings between the Chief Justice and other Court members with the Minister of Justice, the Prime Minister and parliamentary committees. While unconventional, one discussant praised the ability for such discussions to educate parliamentarians on the judicial perspective in that they help to remind the judges of some of the political realities and political pressures. Finally, one commenter pointed out that the effort to reduce partisanship is not an end in itself, but an effort to ensure the best candidates are appointed to the Court. To that end, the fact that Justice Brown had previously expressed his policy preferences in blogs and speeches ought not to disqualify him from being considered for the job. The need for more transparency and accountability ought not result in the least common denominator.

Finally, many of these concerns and ideas expressed were echoed in the discussions surrounding Senate appointments. ${ }^{21}$ This included various comments surrounding the Supreme Court's Senate Reference ${ }^{22}$ suggesting that the 
Court overreached, and that significant reforms to the Senate selection process could be achieved without a constitutional amendment. There may be a need to move away from our British roots and look serious at a more representative Senate, but there is again a need to explore how the objectives of the Senate as a place for sober second thought fits in today's current Canadian democracy.

\section{F. Conclusion: Reflections on Constitutional Change by Robert Hazell}

Robert Hazell, Professor of Government and the Constitution at University College London, provided an illustrative counterpoint to the discussion throughout the symposium by describing the process of constitutional reform that has taken place in the UK. His remarks are reflected in the summaries of each session, but he also provided a more detailed summary to our deliberations at the end of each day. The following sets out a few of his observations of the UK experience as examples of reform that is possible within the Westminster system.

Hazell's remarks began with the observation that the received wisdom among the media, commentary and public is that Parliament in the UK as an institution is in terminal decline. He then spoke of positive change that has been effective without the need for cumbersome constitutional change to counteract this view. For example, the government established a select committee on the reform of the House of Commons in response to the MP's expense scandal that recommended a back benchers business committee. This has led to increased influence by parliamentarians on budgetary items and agenda setting. He noted that a less well-known Commons Liaison committee has been a force for good by ensuring that select committees have core tasks that enhance overall accountability. He mentioned a study of the impact of such select committees that has shown that in over $40 \%$ of cases, the recommendations by the committees have been adopted by government.
The UK Human Rights Act has enjoyed less public support than the Canadian Charter of Rights and Freedoms. However, it is still seen as a joint responsibility that engages all three branches of government. All bills must be accompanied by a certificate in which the sponsoring Minister states that they are satisfied that the bill is compatible with the ECHR. The Joint committee scrutinizes each bill and can interrogate the Minister about the reasoning behind this assertion.

His reflection on Canada's Senate reform drew from the experience of increased legitimacy of the House of Lords since the removal of the hereditary lords, even without the election of members. He stated that the legitimacy is derived from two things: 1) Membership - the expertise of the members of the House of Lords who are very senior in their fields and independent minded; and 2) Output - the earned legitimacy through work scrutinizing legislation and of the Lords' constitution committee. He cautioned that it might be unwise to have an upper house composed entirely of independent, non-partisan Senators as it might become an unmanageable chamber.

One of the most significant UK reforms that has taken place is the regulation of public appointments. Sixty of the top public appointments of boards, agencies, and commissions one-step removed from government require preappointment scrutiny hearings. While the select committee has no veto power, negative reports have had an impact with candidates withdrawing or the Minister then declining to appoint.

In Hazell's concluding thoughts on the second day of the symposium, he spoke of the judicial appointments process in response to the discussion on Supreme Court appointments in Canada. He noted that the UK has taken the opposite approach and set up an independent judicial appointments committee (a direction in which Canada now seems to be moving). Criticism of their system is that the committee only submits one name leaving the Lord Chancellor with no choice and that the committee itself is controlled by senior judges leaving little accountability and slow progress on diversity. Finally, 
he noted that there have been positive developments in judicial engagement with government. The Lord Chief Justice has monthly meetings with the Minister of Justice, meeting twice a year with the Prime Minister and regular annual outings before parliamentary committees. This is seen as a genuine dialogue between the judiciary and the legislative branch, and while it might shock Canadians and Australians as threatening to judicial independence, it has shown to be beneficial to both sides primarily to educate each.

\section{APPENDIX A}

\section{List of Presenters}

\section{A. Democratic Processes: elections, funding duration, franchise, omnibus bills, retroactive legislation, government formation}

Adam Dodek

The Constitutional Problems of Omnibus Budget Bills

\section{Hugo Cyr \\ Government Formation \\ Yasmin Dawood \\ Current Challenges in Election Law and the Possibilities for Electoral Reform \\ Josh Hunter \\ Limits on Proposed Democratic Institutions Reforms without Constitutional Amendments}

\section{B. Constitutionalism, Administration of Justice, and Rule of Law}

Mark Walters

Executive Prerogative and Constitutional Duties

Cara Zwibel

Commons Committees and the Constitution

Vincent Kazmierski

Accessing with Dinosaurs; Key Steps to Increasing Access to Information in Canada

Jennifer Raso

Access to Information and Constitutional Democracy: Who Counts?
Charlie Feldman

Charter Compliance and the Parliamentary Process: Questions of Design

C. Democratic Function: Roles of the House of Commons, Senate, Cabinet, PMO, and Individual Ministers

\section{Mel Cappe}

Comments on the Role of the PCO \& PMO

Peter Russell

Constitutional Conventions and Democratic Illiteracy

Bruce Ryder

Reining in the Imperial Prime Minister: Executive Power and the Rule of Law

Benjamin Hanff

Conventions and Political Marketing

\section{Constitutional Governance and} Litigation

\section{Carissima Mathen}

Government Response to the Outcomes of Constitutional Litigation

Hon. Irwin Cotler

E. Public Appointments: Procedure, Independence, Merit, and Transparency

John Whyte

Appointments to the Supreme Court of Canada

David Schneiderman

Supreme Court Appointment Processes

Errol Mendes

Constitutional Options After the Supreme Court Decision in Ref. re. Senate Reform

\section{F. Conclusion: Reflections on Constitutional Change}

\section{Robert Hazell}

Robert Hazell is a Professor of Government and the Constitution at University College London. 


\section{Program Co-Chairs}

Lorraine Weinrib

Faculty of Law, University of Toronto

Cheryl Milne

Executive Director, David Asper Centre for

Constitutional Rights, University of Toronto

Patricia Paradis

Executive Director, Centre for Constitutional

Studies, University of Alberta

\section{APPENDIX B}

\section{Working Dinner Questions and Ideas}

1. We are now getting used to the dramatic changes precipitated by the recent election and moving toward the $150^{\text {th }}$ anniversary of the birth of the Canadian state. Looking back and looking forward, can we work out a template of the most urgent topics and themes for constitutional development and renovation?

- Reconciliation with Canada's indigenous peoples: ensure representation in the Senate; bring indigenous legal traditions into the constitutional fold; consider parallel indigenous elections

- Time to step back and acknowledge that we are not governing well: we need a strategic, organizational rethink because we don't understand what democracy truly means for this country

- Recognizing the significance and reconciling the place of three unique and foundational governments or governing bodies within Canada:

$\diamond$ Quebec as distinct from other provinces

$\diamond \quad$ Indigenous peoples as self-governing nations

$\diamond$ Municipalities a central but constitutionally invisible level of government

- Considereducation as a federal responsibility
- Focus on the independence of the institution of the Senate - have a Senate strategy

- Increasing need for our Parliament to evolve

2. Given our history of formal and informal constitutional change, and the example that recent constitutional development in the United Kingdom provides, what should we include in an agenda for short and long terms projects to update and fill gaps in the structure and operation of Canada's constitutional democracy?

- Replicate the improved accountable and effective governance experienced by the UK through merit based appointments to the Senate and other administrative bodies

- Appointing powers across the board should be organized and unified - institutionalize this approach

- Improve associational life for Canadians with greater opportunities to participate in bodies such as constituents' assemblies; be aware that participatory democracy requires that Canadians have time to participate which might disenfranchise those who must work multiple jobs or long hours to pay for basic necessities

- Discussions need to take place about the role of accountability officers such as ombudspersons, auditors, lobbyist registrars and others

- Hire more information coordinators to improve access to information

- Consider a joint committee of the Senate and House to review legislation for its constitutionality

- Manuals for constitutional conventions (should be educational) 


\section{APPENDIX C \\ Discussion Questions}

A. Democratic Process: elections, funding, duration, franchise, omnibus bills, retroactive legislation, government formation

Omnibus Bills

$\diamond 1$. What should be the role of the House in curbing omnibus/budget bills?

$\checkmark 2$. What should be the role of the Senate?

$\checkmark 3$. What should be the role of the Governor General?

$\checkmark 4$. What should be the role of the Courts?

Government Formation

$\diamond 1$. What should we do to push forward idea of creating a Cabinet manual? Should we do it through federal government? Or, for strategic reasons, should it be done through provinces and then export model?

$\diamond 2$. What should be done with the media?

$\checkmark 3$. How should electoral reform impact our conventional rules? Should we redirect focus to the candidates rather than merely the leader?

Electoral Reform

$\diamond 1$. Should it be up to voters to decide whether or not to change the electoral system? Is public consultation required, as a legal matter or a matter of principle? If so is there something distinctively different about electoral reform as compared to other kinds of decisions being made by the Liberal government that are not being subjected to referendum? What role ought voters to have in questions like this? $\checkmark$ 2. Does the Liberal government have a mandate to change the system? They have suggested that a Liberal win means a mandate for electoral reform from voters. Is this the case? Does that reflect what voters were doing when they voted Liberal?

$\checkmark 3$. Should the provinces have a say in electoral reform at the federal level? Is this something that requires a formal constitutional amendment process?

Limits on Reform without Constitutional Amendment

$\checkmark 1$. What do we think is the improper use of omnibus bills and prorogations? Or is there a proper use of either?

$\checkmark$ 2. On electoral reform, what do we think is a preferred form and why? Or is the current system the best of a bad lot?

$\checkmark 3$. What should be the role of a less partisan Senate in our bicameral structure?

\section{B. Constitutionalism, Administration of Justice and Rule of Law}

Review of Ministerial Advice

$\diamond 1$. What are the dangers of overjudicialization?

$\diamond 2$. Is it even realistic to expect that ministers giving advice to Governor General or Lieutenant General must give reasons publicly for what they advised that can then be tested constitutionally? Or does it interfere with a confidential relationship that shouldn't be exposed?

Commons Committees and the Constitution

$\checkmark 1$. Are there ways to make the committee process more open and more of a public forum while maintaining need for efficient consideration? 
$\diamond 2$. What would help a committee in addressing constitutional vulnerabilities raised by witnesses?

$\diamond 3$. Are these case studies really just isolated moments in a particularly partisan government, and can we expect something different from our new committees and government?

Access to Information

$\diamond 1$. Why aren't we paying more attention to access to government information?

$\checkmark 2$. What is the proper balance between effective governance and accountable governance? Where should we draw the line?

$\checkmark 3$. What is the legitimate role of the courts in trying to achieve that balance between effective governance and accountable governance?

Collecting Information

$\diamond$ 1. Understanding that the information these agencies produce is political, what is or ought to be the role of these agencies and the role of the information they produce within a constitutional democracy?

$\diamond 2$. How should we acknowledge the importance of the data they produce both as practical tool and as symbolic tool over representation of Canadians in data?

$\diamond 3$. What other avenues might exist for ensuring that these institutions and their data are protected and valued going forward?

Charter Compliance and the Review Process

$\diamond 1$. By what standard, with what actors, and when should Parliament be informed of concerns under the Charter? $\checkmark 2$. What should accountability be when it comes to addressing problems?

$\checkmark$ 3. Should this be a role for Parliament at all? Should the courts be handling oversight on these issues, rather than relying on self-governance?

\section{Democratic Function: House of Commons, the Senate, role of Cabinet and individual Ministers, PMO}

Role of the PCO and PMO

$\diamond 1$. Is increasing centralization inevitable?

$\diamond$ 2. Shouldn't the clerk be dealing with the opposition to prepare them for government?

$\diamond 3$. Which is worse - marginalization or politicization?

Constitutional Conventions and Democratic Illiteracy

$\diamond 1$. Should Canada have a cabinet manual?

$\diamond$ 2. If so, what process should be used to produce it?

$\checkmark 3$. If it can't be done federally, should we do it at the provincial level? Should we do both levels at the same time?

Executive Power and the Rule of Law

$\diamond 1$. Are there areas where the prerogative should be left untouched or should those and others be legislated?

Constitutional Conventions

$\checkmark 1$. Have we entered a political era where the idea of conventions as interpreted and applied by political actors is obsolete and we need court review? 


\section{Constitutional Governance and Litigation}

Government Response to Litigation Outcomes

$\diamond 1$. How should governments and their lawyers view constitutional litigation?

$\diamond 2$. What role might a reinvigorated court program play in that? Should it spur a new relationship?

$\diamond 3$. How do we work productively with new government and its lawyers?

$\diamond \quad 4$. To what extent can we expect a level of good faith and statesmanship from political actors to inform what is clearly a highly political office?

\section{E. Public Appointments: procedure, independence, merit and transparency}

\section{Supreme Court Appointments}

$\diamond$ 1. Is partisanship inherent in a hearing process? Or is there a bigger interest that can attract people's moral positions?

$\diamond \quad 2$. Will hearings politicize the law and the judiciary?

$\diamond$ 3. Can legislators conduct conversations about the nature of constitutional decision-making?

$\diamond 4$. What does a self-determining nation do when it needs to reform its national government but is already claiming it cannot be a self-determining nation? Can we create new conventions, and can they become enforceable - can they constitutionalize around this problem?

$\checkmark 5$. What is the rationale for making the process more public? Transparency? Constitutional literacy?

$\diamond \quad 6$. How do we balance accountability with partisanship?

$\diamond 7$. What about parameters for questioning?
Senate Appointments

$\diamond 1$. Because they didn't elaborate on the parameters of the architecture of the constitution, what can one deduce from that?

$\diamond 2$. If we accept that this process is constitutional, why do we still follow the British model and say that there's a part of our legislature that is legitimately not democratically elected? What is it about this that we can still justify it?

\section{Endnotes}

1 Cheryl Milne is the Executive Director of the David Asper Centre for Constitutional Rights and was co-chair of the symposium, along with Lorraine Weinrib, Professor of Law, Faculty of Law, University of Toronto and Patricia Paradis, Executive Director of the Centre for Constitutional Studies, University of Alberta; John Griess is an LL.M. Candidate and Deborah Boswell is a recent JD graduate of the Faculty of Law, University of Toronto. This summary draws on the symposium notes taken by student volunteers at the Faculty of Law, University of Toronto: Deborah Boswell, Geneviève Ryan, Dragana Rakic, Neil Abraham, Eleanor Vaughn, Cindy Zhou, Ramz Asis, Yasin Razak and Jennifer Che.

2 The Asper Centre for Constitutional Rights is a centre within the University of Toronto, Faculty of Law, devoted to advocacy (including constitutional litigation), research and education in the areas of constitutional rights in Canada (see: <www. aspercentre.ca/who-we-are.htm>).

3 The Center for Constitutional Studies is supported by the Alberta Law Foundation and the University of Alberta, Faculty of Law (see: $<$ https://ualawccsprod.srv.ualberta.ca/index. php/about-us $>$ ). It is dedicated to constitutional research and public education in Canada. It publishes an academic journal, the Review of Constitutional Studies, as well as an online journal, the Constitutional Forum.

4 Robert Hazell, University College London.

5 While we did not undertake to comply with Chatham House rules, we have adhered to this convention in summarizing the discussion. We have identified with attribution where published 
papers further expand upon the themes, either by way of background or published in the Constitutional Forum as part of this special edition. A list of presenters can be found at Appendix A.

6 Hugo Cyr, «De la formation du gouvernement» (2013) 43:2 RGD 381 at 383.

7 Josh Hunter, "Renovating Canada's Constitutional Architecture: An Examination of the Government's Democratic Reform Initiatives" (2016) Constitutional Forum [Hunter].

8 Reference re Supreme Court Act, ss. 5 and 6, 2014 SCC 21, [2014] 1 SCR 433.

9 Reference re Senate Reform, 2014 SCC 32, [2014] 1 SCR 704.

10 See e.g. Hunter, supra note 7.

11 Mark Walters, "Judicial Review of Ministerial Advice to the Crown" (2016) Constitutional Forum; Charles Feldman, "Legislative Vehicles and Formalized Charter Review" (2016) Constitutional Forum.

12 Cara Zwibel, "The Committee Process: Platform for Participation or Political Theatre?” (2016) Constitutional Forum.

13 Vincent Kazmierski, "Accessing with Dinosaurs: Protecting Access to Government Information in the Cretaceous Period of Canadian Democracy" (2016) Constitutional Forum.

14 Jennifer Raso, "Accessible Information and Constitutional Democracy: Who Counts?” (2016) Constitutional Forum.

15 Roncarelli v Duplessis, [1959] SCR 121, 16 DLR (2d) 689 .

16 Ibid at 142.

17 Peter Russell, "A Project to Reduce Canadians' Constitutional Illiteracy" (2016) Constitutional Forum.

18 Carissima Mathen, "Government Responses to Constitutional Litigation: Lessons from Recent Canadian History" (2016) Constitutional Forum.

19 Canada (Prime Minister) v Khadr, 2010 SCC 3, [2010] 1 SCR 44.

20 John Whyte, "Political Accountability in Appointments to the Supreme Court of Canada," (2016) Constitutional Forum; see also David Schneiderman, Red, White, and Kind of Blue?: The Conservatives and the Americanization of Canadian Constitutional Culture (Toronto: University of Toronto Press, 2015) ch 5.

21 Errol P Mendes, "Constitutional Options After the Supreme Court's Decision in Reference Re Senate Reform; Restoring Trust and Credibility Through Senate Reform" (2015) 35:1 NJCL 85.

22 Supra note 9. 